\title{
Working Conditions in Selected Private College Libraries
}

\author{
BY DONALD E. THOMPSON
}

Although Library Literature reveals that several general articles have been published during the past five years on hours of work, hours of opening, annual vacations, special vacations, faculty rank or status, and sabbatical leaves for librarians, there have been no studies of specific groups of colleges on a broad scale. In order to develop such information, a questionnaire was sent to the librarians of sixty private liberal arts colleges. The forty-nine who replied were Amherst, Anderson, Antioch, BaldwinWallace, Bates, Beloit, BirminghamSouthern, Bowdoin, Bryn Mawr, Bucknell, Carleton, Clark (Massachuetts), Colby, Colgate, Colorado College, Denison, DePauw, Dickinson, Earlham, Franklin, Goshen, Hamilton, Haverford, Heidelberg, Hope, Kalamazoo, Lafayette, Lawrence, Lewis \& Clark, Macalester, MacMurray, Manchester, Middlebury, Mills, Monmouth, Mount Holyoke, Muhlenberg, Ohio Wesleyan, Reed, Ripon, St. Joseph's (Indiana), Swarthmore, Vassar, Wabash, Wellesley, Wesleyan, Wheaton (Illinois), Williams, and Wittenberg. The information received, which is as of January 1964, is given here only in summary.

One question asked concerned the hours of work per week for the regular school year and for vacation periods. This was requested for professional, semiprofessional, and clerical and secretarial library staff, and for the clerical and secretarial staff in other college offices. The number in parentheses indicates the number of institutions for the particular category.
Mr. Thompson is Librarian of Wabash College, Crawfordsville, Indiana.

Hours of work per week for professional library staff

School year

$\begin{array}{llll}35(3) & 38(5) & \text { Low } & 35 \\ 36(1) & 38.5(3) & \text { Median } & 38.5 \\ 37(1) & 39(3) & \text { High } & 40 \\ 37.5(12) & 40(19) & \text { Average } & 38.5\end{array}$

Vacation periods

$\begin{array}{llll}30(2) & 37.5(6) & \text { Low } & 30 \\ 32.5(2) & 38(2) & \text { Median } & 35 \\ 33(1) & 39(2) & \text { High } & 40 \\ 35(20) & 40(8) & \text { Average } & 36.2\end{array}$

Hours of work per week for semiprofessional library staff

School year

$\begin{array}{llll}35(4) & 38.5(2) & \text { Low } & 35 \\ 37(1) & 39(3) & \text { Median } & 39 \\ 37.5(8) & 40(19) & \text { High } & 40 \\ 38(3) & & \text { Average } & 38.6\end{array}$

Vacation periods

$\begin{array}{llll}30(2) & 38(1) & \text { Low } & 30 \\ 32.5(2) & 39(2) & \text { Median } & 35 \\ 35(18) & 40(8) & \text { High } & 40 \\ 37.5(4) & & \text { Average } & 38.9\end{array}$

Hours of work per week for clerical and secretarial library staff

School year

$\begin{array}{llll}35(4) & 38.5(2) & \text { Low } & 35 \\ 37(2) & 39(2) & \text { Median } & 39.5 \\ 37.5(10) & 40(23) & \text { High } & 40 \\ 38(3) & & \text { Average } & 38.6\end{array}$


Vacation periods

$\begin{array}{llll}30(2) & 38(1) & \text { Low } & 30 \\ 32.5(2) & 39(1) & \text { Median } & 35 \\ 35(17) & 40(9) & \text { High } & 40 \\ 37.5(8) & & \text { Average } & 36.4\end{array}$

Hours of work per week for college (nonlibrary) staff

$\begin{array}{clll}\begin{array}{c}\text { School year } \\ 35(6)\end{array} & 38.25(1) & \text { Low } & 35 \\ 35.5(1) & 38.5(1) & \text { Median } & 38 \\ 36.5(1) & 38.75(1) & \text { High } & 40 \\ 37(1) & 39(2) & \text { Average } & 38.2 \\ 37.5(12) & 40(17) & & \\ 38(2) & & & \\ \text { Vacation periods } & & \\ 30(2) & 38(1) & \text { Low } & 30 \\ 32.5(3) & 38.25(1) & \text { Median } & 37.5 \\ 35(12) & 38.75(1) & \text { High } & 40 \\ 37(1) & 39(1) & \text { Average } & 36.7 \\ 37.5(8) & 40(10) & & \end{array}$

Annual vacations were requested in working days, but several answers were given in terms of months, weeks, and hours. Since these categories do not make comparison easy, the vacation periods are presented in outline form. Where there is a range given (i.e., 2-4 weeks), this usually means two week's vacation after the first year and an increase to four weeks after a given number of years.

Annual vacation for professional library staff

\begin{tabular}{|c|c|}
\hline Worki & Days \\
\hline $20(7)$ & $28(1)$ \\
\hline $21(1)$ & $30(2)$ \\
\hline $22(9)$ & $35(2)$ \\
\hline $23(3)$ & $20-40(1)$ \\
\hline $\begin{array}{l}24(1) \\
26(2)\end{array}$ & $30-40(1)$ \\
\hline
\end{tabular}

Weeks

4(3) 2-4(1)

$5(1) \quad 4-6(1)$

one month (8)

240 hours (1)

Annual vacation for semiprofessional library staff

\begin{tabular}{|c|c|c|c|}
\hline Work & Days & \multicolumn{2}{|c|}{ Weeks } \\
\hline $10(5)$ & $26(2)$ & $2(1)$ & $4(1)$ \\
\hline $15(1)$ & $28(1)$ & $3(3)$ & $2-4(1)$ \\
\hline 18(1) & $5-10(1)$ & & \\
\hline $20(2)$ & $10-20(4)$ & one $\mathrm{n}$ & nth \\
\hline
\end{tabular}

\section{2(4) $\quad 10-22(1)$ \\ 23(2) 21-22(1) 105 hours (1) \\ 24(1)}

Annual vacation for clerical and secretarial library staff

$\begin{array}{lll}\text { Working Days } & \text { Weeks } \\ 10(9) & 5-10(1) & 2(3) \quad 1-4(1) \\ 12(2) & 5-16(1) & 3(3) \quad 2-4(2) \\ 15(1) & 10-15(1) & 4(1) \\ 20(2) & 10-20(4) & \\ 22(4) & 10-22(1) & \text { one month (3) } \\ 23(1) & 11-15(1) & \\ 24(1) & 14-21(1) & 105 \text { hours (1) }\end{array}$

Annual vacation for college (nonlibrary) staff

$\begin{array}{lll}\text { Working Days } & \text { Weeks } \\ 10(12) & 5-10(1) & 2(4) \quad 1-4(1) \\ 12(2) & 5-16(1) & 3(2) \quad 2-3(3) \\ 15(1) & 10-15(2) & 4(1) \quad 2-4(1) \\ 20(1) & 10-20(5) & 1-3(1) \\ 22(1) & 10-22(1) & \\ 23(1) & 11-15(1) & \text { one month (3) } \\ 24(1) & & \end{array}$

The question on special vacations asked for the number of working days of extra vacation allowed during Easter, Thanksgiving, and Christmas. This was meant to be over and above the times when the library would normally be closed, such as Sunday and legal holidays. This was answered in so many ways that it was difficult to tabulate. In some cases there was just a listing of four or five legal holidays; in other cases a number of days was listed. For most institutions the same special vacations applied to library and nonlibrary personnel. The special vacations ranged from only the legal holidays to all of the Easter, Thanksgiving, and Christmas vacations. The average, or median, was four to six working days in addition to New Years Day, Fourth of July, Labor Day, Thanksgiving Day, and Christmas Day.

The figures below indicate the number of hours the library is open. These fig-

(Continued on page 294) 
recognizes the fact that the library must be more than just a place to store books; it must also be an excellent place for study, an attractive place to browse. The reading rooms must have more comfortable seats and tables, inviting in decor and attractive in furnishings. Private student carrels and faculty studies are provided to serve those students and faculty members who need some element of privacy for concentration and study.

The library collection needs to be strengthened not only in printed materials but also in such media as microfilms, microcards, and other audio-visual materials related to the academic program and the researches that are done in Silliman University. The administration also hopes to make the library services even more effective with the use of modern library equipment such as book charging machines. More of the time of the professional staff must be devoted to reader guidance, the preparation of bibliographies, and the indexing and abstracting of articles and books that have research and professional value. Ultimately, the Silliman University library hopes to become the bibliographical center in the Visayas.

With a vitalized educational program at Silliman University and its dedication to the pursuit of excellence in education, new challenges and opportunities for greater library services present themselves. These challenges can be met with quality library facilities, quality library collections, and quality staff members. "This triad is indivisible for one cannot exist without the others, and each needs to be excellent in itself if educational objectives are to be realized."

\footnotetext{
"Flora Belle Ludington, "Books and Libraries: Tools of the Academic World," in Of, By, and For Librarians, comp. by John David Marshall (Hamden, Conn.: Shoe String Press, 1960), p.106.
}

\section{WORKING CONDITIONS ...}

(Continued from page 262)

ures do not include the extra hours one room is open for study only.

School Year Vacation Periods

$\begin{array}{lll}\text { Low } & 62.5 & 15 \\ \text { Median } & 85 & 40 \\ \text { High } & 101 & 64 \\ \text { Average } & 84.5 & 39.4\end{array}$

In requesting information about faculty rank or status, no attempt was made to distinguish between the two or to inquire about details of faculty titles. It was found that twenty-five institutions give faculty rank or status to all librarians, twelve give it only to the head librarian, nine give it to specific staff members (usually department heads and higher), and three do not give it to any staff member.

In the question about sabbatical leave, some answers implied that it was auto- matic for certain or all library staff members, while some answers indicated that library staff members could apply for sabbatical leave. A summary showed that thirteen institutions give sabbatical leave to all librarians; eight give it to the head librarian only; two give it to the head librarian, assistant librarian, and department head; and twenty-six have no definite policy or did not answer the question.

Most of the questionnaires had an answer about the type of sabbatical leave in effect at the institution. The most-used plan is full pay for one semester or half pay for two semesters. Some institutions have variations, such as one semester with full pay or one year with half pay. Those institutions on the quarter system usually give one quarter with full pay, two quarters with two-thirds pay, and three quarters with half pay. In a few cases, leave was granted without pay. 